\title{
Peningkatan Budaya Literasi Anak di Taman Kanak-Kanak Nurul Fikri Bekasi Utara
}

\author{
Ellita Permata Widjayanti ${ }^{1}$, Fadilla Ayuningtyas ${ }^{2}$ \\ Universitas Negeri Jakarta ${ }^{1,2}$, \\ ellita.permata@gmail.com ${ }^{1}$, fadillaayuningtyas@gmail.com²
}

\begin{abstract}
In this millennial era our society's ability to read is increasingly eroded by the presence of technology. Gadget is not only enjoyed by adults, but also by children even from an early age. At TK Nurul Fikri, Alamanda Regency Housing in North Bekasi, 100\% of parents said that they gave a gadget to their children. Mothers also have a relatively low level of education. The Community Empowerment Program is carried out through an awareness method by providing material and training related to child care in the digital era. This program involves speakers and trainers who have been involved in parenting world. The storytelling training programs, which was carried out to improve maternal skills in educating children, are also supported by training in making story-telling materials from used goods. Through the skill playing method, children are also stimulated to be closer to literacy culture. Through this program, mothers become more open-minded and trained to build their children literacy culture. Thus children are expected to get more positive values from their close environment.
\end{abstract}

Keywords: Millennial; Culture; Literacy; Children.

\begin{abstract}
Abstrak
Di era milenial ini kemampuan membaca masyarakat semakin tergerus dengan kehadiran teknologi. Gawai tidak hanya dinikmati oleh orang dewasa, namun juga oleh anak-anak bahkan sejak usia dini. Data menunjukkan sebanyak 100\% orang tua anak di TK Nurul Fikri, Perumahan Alamanda Regency Bekasi Utara, menyatakan bahwa mereka memberikan gawai pada anak-anak mereka. Kesadaran akan dampak negatif gawai belum sepenuhnya dipahami oleh para ibu, sehingga belum ada hal berarti yang dilakukan dalam rangka mencegahnya. Program Pemberdayaan pada masyarakat ini dilakukan melalui metode penyadaran dengan pemberian materi lewat kelas parenting yang berkaitan dengan pola asuh anak di era digital. Kelas parenting melibatkan para pembicara dan trainer yang sudah berkecimpung di dunia pendidikan anak. Kelas parenting juga menyediakan training mendongeng bagi ibu untuk mendukung literasi di rumah serta pelatihan keterampilan membuat media dan bahan bercerita dari barang bekas. Selain itu, program pemberdayaan juga melibatkan anak-anak dalam kegiatan penumbuhan kecintaan pada buku di sekolah dan di rumah lewat permainan yang menyenangkan. Melalui program pemberdayaan ini, para ibu menjadi lebih terbuka wawasannya dan terlatih untuk membangun budaya literasi anak di rumah. Hal ini diharapkan mendukung peningkatan budaya literasi anak sejak usia dini.
\end{abstract}

Kata kunci: Milenial; Budaya; Literasi; Anak-anak. 


\section{A. PENDAHULUAN}

Berdasarkan hasil survei Central Connecticut State University atau CCSU (2016) dalam World's Most Literate Nations Ranked tentang pemeringkatan perilaku literasi dan sumber yang mendukung literasi di 61 negara, Indonesia berada di urutan 60 jauh berada di bawah Malaysia dan Singapura. Hasil ini sangat memprihatinkan, karena penelitian menunjukkan bahwa kemampuan literasi sangat menentukan keberhasilan suatu bangsa menyongsong ekonomi berbasis pengetahuan masa sekarang (Freire et al, 2005).

Budaya literasi khususnya membaca seharusnya dimulai sejak usia dini sehingga orang tua dapat membentuknya dalam kebiasaan, sikap dan karakter anak dimasamasa keemasan. Membaca berperan penting membentuk sikap dan kepribadian bagi kehidupan anak, karena lewat membaca anak akan belajar nilai-nilai. Namun, kebiasaan membaca saat ini semakin jauh berkurang.

Berdasarkan Survei Sosial Ekonomi Nasional, konsumi media di Indonesia pada 2015 mencapai 91,5\% (Badan Pusat Statistik, 2015). Selain itu, survei Digital in 2017: Southeast Asia merilis $11 \%$ masyarakat Indonesia menonton video online setiap hari, $42 \%$ bermain game, dengan menghabiskan waktu rata-rata 8 jam 44 menit menggunakan internet lewat Personal Computer (PC) dan tablet (Social and Hootsuite, 2017). Hal ini memperlihatkan, kehadiran gawai serta perangkat teknologi komunikasi di masyarakat telah menggeser minat baca masyarakat. Gawai membuat anak lebih senang bermain game dan menonton video online daripada membaca buku.

Selain kehadiran gawai, sulitnya akses buku-buku berkualitas dan kondisi perpustakaan di Indonesia juga dianggap berpengaruh pada rendahnya literasi pada anak. Pada tingkat sekolah dasar, dari
147.503 sekolah yang ada baru sekitar $61,45 \%$ atau 90.642 sekolah yang memiliki perpustakaan dengan kondisi yang bebas dari rusak ringan-total hanya 28.137 , atau tersisa 19\% dibandingkan jumlah sekolah (Kemendikbud, 2016).

Pembangunan budaya literasi memerlukan kerjasama dari berbagai pihak, terutama dari lingkungan keluarga dan sekolah. Sekolah harus mendorong anak untuk menyukai aktivitas membaca dan keluarga harus memberikan dukungan dengan membangun budaya literasi di rumah. Oleh karena itu orang tua harus menyadari urgensi budaya literasi dan pola pengasuhan yang mendorong ke arah tersebut.

Sebagai upaya berkontribusi dalam peningkatan literasi anak di Indonesia, maka tim program pemberdayaan masyarakat Fakultas Bahasa dan Sastra Universitas Negeri Jakarta (FBS UNJ) membuat berbagai kegiatan bertemakan literasi di Taman Kanak-Kanak (TK) Nurul Fikri, Bekasi Utara.

TK Nurul Fikri merupakan institusi yang didirikan secara swadaya oleh seorang ibu rumah tangga yang berinisiatif untuk membantu pendidikan anak usia dini di lingkungan perumahan Alamanda Regency, Bekasi Utara. Perumahan ini mayoritas dihuni oleh masyarakat kalangan menengah ke bawah, sehingga sekolah tidak memungut biaya yang besar pada siswanya, tercatat sekitar 75.000-100.000 per bulan. Sekolah ini tidak banyak memberikan fasilitas bermain baik luar maupun didalam kelas, serta tidak pula menyediakan buku dan perpustakaan untuk anak.

Berdasarkan survei awal, tercatat $100 \%$ orang tua memberikan gawai kepada anaknya di usia dini. Gawai ini diberikan kepada anak untuk bermain game. Selain itu, data awal menunjukkan bahwa para ibu menyadari dampak negatif dari gawai, namun mereka belum sepenuhnya 
memberikan pendampingan pada anak terhadap penggunaannya. Peneliti berasumsi bahwa anak-anak di lingkungan ini masih kurang dipajankan pada buku bacaan anak dan lebih banyak bermain dengan gawainya. Para orangtua di lingkungan ini juga belum membangun budaya literasi di rumah mereka.

Permasalahan yang dapat dirumuskan dalam kegiatan ini berfokus pada (1) bagaimana menghidupkan budaya literasi anak, (2) bagaimana meningkatkan kesadaran orang tua dalam membangun kebiasaan membaca di rumah, dan (3) bagaimana meningkatkan keterampilan dan pengetahuan orang tua dalam pola asuh anak yang membentuk budaya literasi anak.

Berdasar permasalahan tersebut, peneliti merancang kegiatan berupa kelas parenting dan kelas anak. Para ibu akan mendapatkan materi mengenai strategi pengasuhan anak di era milenial, strategi meningkatkan budaya baca di rumah, pelatihan mendongeng dan pelatihan membuat bahan edukasi anak dari barang bekas dalam kelas parenting.

Sedangkan pada kelas anak, dirancang berbagai permainan kreatifitas yang merangsang peningkatan keterampilan bahasa anak dan kecintaan anak pada buku. Selain itu dibuat program One Book One Child (OBOC) yang terintegrasi dengan kelas parenting yang memungkinkan anak untuk berinteraksi dengan buku melalui bimbingan orang tua dan guru.

\section{B. PELAKSANAAN DAN METODE}

Konsep pemberdayaan, menurut Gunawan Sumodiningrat dalam Suryanto (205) dapat dilihat dari tiga sisi. Pertama, pemberdayaan dengan menciptakan suasana atau iklim yang berkembang. Kedua, pemberdayaan untuk memperkuat potensi ekonomi atau daya yang dimiliki masyarakat. Ketiga, pemberdayaan melalui pengembangan ekonomi rakyat dengan cara melindungi dan mencegah terjadinya persaingan yang tidak seimbang.

Pada kegiatan ini, pemberdayaan dilihat dari sisi pertama dan kedua. Pada sisi pertama, program ini dilakukan untuk merespon situasi yang sedang berkembang, yaitu era milenial, dan untuk menciptakan iklim kebiasaan membaca yang baik di lingkungan masyarakat. Kedua, program yang dilakukan ini dirancang untuk meningkatkan akses pendidikan anak, yaitu akses terhadap buku-buku. Selain itu, program ini juga dirancang untuk meningkatkan akses pengetahuan orang tua terhadap ilmu parenting.

Metode yang digunakan dalam kegiatan ini adalah (1) Penyadaran terhadap masalah, dengan memberikan materi kepada para ibu mengenai pola asuh anak terutama di era digital, (2) Training, dengan melatih para ibu untuk menjadi pendongeng dan juga untuk membuat bahan bercerita dengan barang bekas, dan (3) Permainan, khususnya untuk anak-anak dengan memberikan mereka berbagai permainan kreatif untuk merangsang minat literasi mereka.

Target peserta dari kegiatan pemberdayaan ini adalah para ibu wali murid sejumlah 27 orang dengan data tingkat pendidikan ibu yakni Sekolah Menegah Atas (90\%), dan sisanya Sekolah Menengah Pertama (SMP) dan Diploma tiga (D-3). Selain itu diketahui pula sebanyak $90 \%$ dari mereka bekerja dirumah (ibu rumah tangga), dan $10 \%$ sebagai pedagang. Selain para ibu, kegiatan ini juga menyasar murid TK Nurul Fikri yang juga berjumlah 27 orang. 


\section{HASIL DAN PEMBAHASAN}

Kegiatan peningkatan budaya literasi anak di TK Nurul Fikri terlaksana sebanyak lima kali pertemuan. Adapun kegiatan yang dilaksanakan terdiri dari dua macam kelas, yaitu kelas para ibu (kelas parenting) dan kelas anak.

\section{Kelas Parenting}

Kegitan yang termasuk dalam kelas parenting ini pada mulanya ditujukan untuk orang tua siswa, namun pada pelaksanaannya dilapangan ternyata mendapatkan respons positif dari warga sekitar, sehingga acara ini juga diikuti para ibu di area sekitar sekolah sasaran. Kegiatan kelas parenting ini dilaksanakan lima kali sejalan dengan kegiatan-kegiatan yang ditujukan untuk anak.

1) Pendidikan Anak di Era Milenial

Program ini dilaksanakan pada tanggal 20 Juli 2018 dengan pembicara koordinator Bidang Perlindungan Khusus Anak Forkomnas pada Pemberdayaan Perempuan dan Perlindungan Anak (P3A) sekaligus konsultan keluarga di Pusat Pelayanan Terpadu Pemberdataan Perempuan dan Anak (P2TP2A) Jawa Barat. Tema yang diangkat berkaitan dengan strategi mendidik anak diera milenial. Pertemuan ini menjadi pembuka wawasan orang tua untuk lebih menguatkan peran mereka sebagai tiang utama dalam pendidikan anak terutama di era milineal, terlebih membentengi anak dari pengaruh buruk gawai dan memaksimalkan fungsi positif gawai.

2) Membangun Budaya Baca Anak

Program yang dilaksanakan pada tanggal 3 Agustus 2018 ini menekankan penguasaan materi budaya literasi pada anak. Tema yang diangkat adalah membangun budaya baca di rumah, dengan narasumber psikolog anak yang menjadi ketua Rumah Keluarga
Indonesia (RKI). Materi pertemuan ini berkaitan dengan urgensi anak-anak untuk mendapatkan banyak pajanan buku bacaan edukatif. Orangtua seharusnya memiliki komitmen untuk berperan membacakan buku dan cerita-cerita edukatif pada anak. Hal ini dapat meningkatkan kemampuan anak berbicara, menangkap kosakata, dan membangun imajinasi dan menjadi sarana menyampaikan nilai-nilai positif pada anak.

Pada pertemuan ini program One Book One Child (OBOC) atau program penyediaan buku bagi setiap anak yang dapat bawa pulang juga disosialisasikan kepada orang tua agar dapat mendampingi anak-anak dan membacakan cerita dirumah. Selain mendekatkan anak pada buku, orang tua diharapkan dapat menggali nilai-nilai positif dari cerita dalam buku untuk disampaikan kepada anak-anak, sehingga nilia-nilai tersebut dapat diinternalisasi menjadi karakter yang positif dalam diri anak.

3) Membangun Literasi Melalui Dongeng

Materi ketiga disampaikan pada tanggal 24 Agustus 2018 oleh para trainer dongeng dengan tema membangun kecerdasan anak melalui dongeng. Materi ini diberikan untuk mengaitkan urgensi mendongeng sebagai bagian dari meningkatkan budaya literasi anak. Menurut Miller dan Pennycuff (2008), mendongeng dapat menghantarkan wawasan secara langsung juga stimulus yang menggugah keinginan anak membaca. Selain itu mendongeng dapat menjadi sarana menanamkan nilai-nilai budi pekerti yang luhur, sesuai dengan kebutuhan dan tahap perekembangan anak. Mendongeng dapat mendekatkan emosi anak dan orang tua serta dapat merangsang kreatifitas berpikir anak. Kesemua urgensi ini menjadi bekal dalam menguatkan kesiapan anak masuk ke sekolah formal.

4) Berkreasi Membuat Bahan Mendongeng 
Kegiatan berkreasi ini dilakukan pada tanggal 7 September 2018. Training ini mengangkat tema berkreasi dengan material bekas untuk bahan edukasi anak, dalam rangka mengajak orang tua memanfaatkan barang bekas sebagai sumber bahan/media literasi anak.

Bahan-bahan bekas yang digunakan seperti botol bekas minuman, buku bekas yang bersampul, gelas plastik bekas air mineral kemudian diajarkan untuk membuat boneka tangan. Boneka botol yang sudah jadi dapat dimasukkan ke dalam jari dan dapat dimanfaatkan sebagai media bercerita atau mendongeng.

Sebagai contoh, pada gambar 1 . menampilkan hasil boneka tangan yang dibuat dari salah satu jenis botol bekas minuman probiotik. Botol ini dapat diubah menjadi media bercerita dengan tema hewan laut seperti gurita, ikan, dan bintang laut.

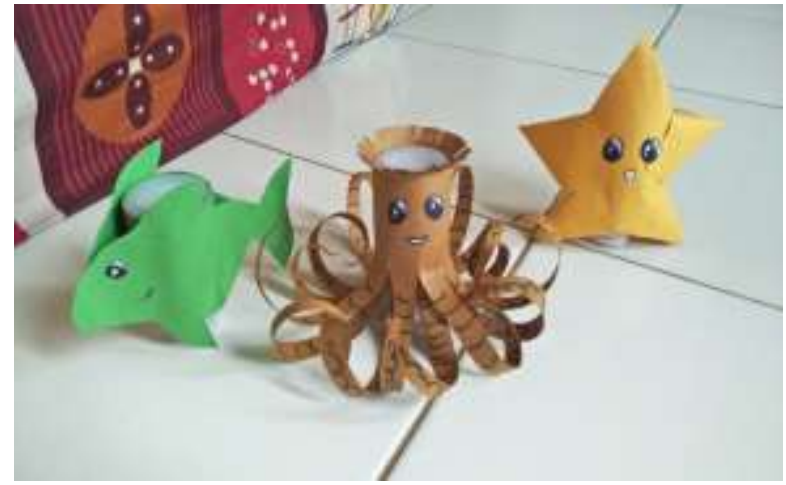

Gambar 1. Boneka jari dari botol bekas

Para ibu sangat antusias dengan kegiatan ini, karena mendapat pemahaman baru memanfaatkan barang-barang yang mulanya selalu dibuang untuk dijadikan bahan yang berguna dalam membangun kesenangan dan ketertarikan anak membaca. Selain itu, disisipkan pula materi membuat bahan atau konten cerita sendiri, sesuai kebutuhan nilai pekerti yang ingin ditanamkan serta kemampuan keaksaraan yang ingin dibangun pada anak.

Diharapkan setelah kegiatan ini, para ibu mampu membuat konten cerita sendiri serta membuat tokoh kreasi dari bahan bekas sesuai dengan tokoh cerita yang menarik bagi anak

5) Berkreasi Membuat Bahan Bercerita (II)

Kegiatan yang diadakan pada tanggal 28 September 2018 ini merupakan kelanjutan dari kegiatan sebelumnya. Para ibu diminta membawa kaos kaki bekas dan gunting. Pelatihan dimulai dengan membuat boneka tangan menggunakan bahan-bahan seperti kain perca atau flannel, kardus bekas, dan lem, serta kaos kaki yang sudah tidak terpakai. Para ibu diajarkan cara membuat boneka tangan berbentuk karakter ular dan buaya.

Hasil boneka tangan yang dibuat oleh para ibu yang menjadi peserta kegiatan berkreasi ditunjukkan oleh gambar 2. Boneka tangan yang dibuat bertema hewan reptil dapat menjadi media bercerita anak yang menyenangkan.

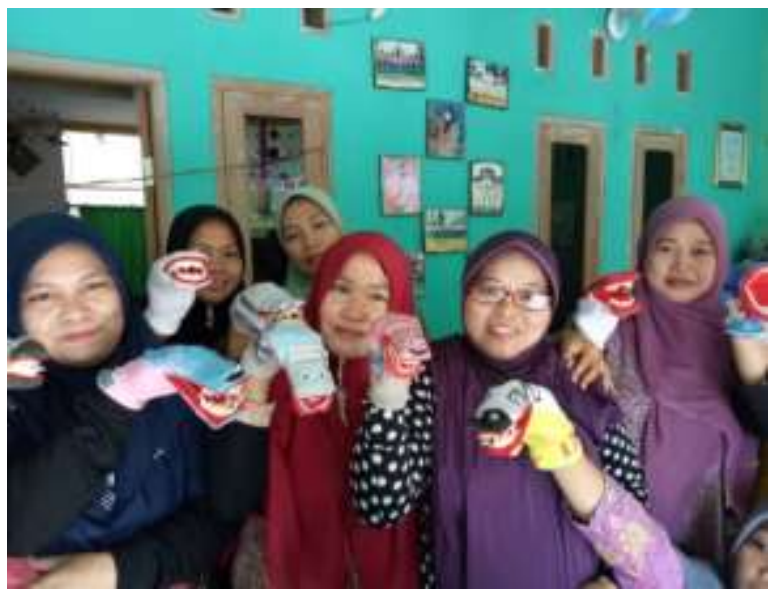

Gambar 2. Para ibu dan hasil karya boneka tangan dari kaos kaki bekas.

Melalui pelatiahan membuat boneka dengan kaos kaki bekas ini, para ibu dilatih untuk berkreasi dengan bahan bekas atau 
bahan-bahan yang murah dan tersedia di sekitar rumah dengan menyesuaikan kemampuan ekonomi dan kebutuhan masingmasing anak.

Pada akhir sesi, para ibu mencoba bercerita dengan boneka tersebut. Pada kesempatan ini, para ibu juga diajarkan memproduksi suara tebal, tipis, tinggi, dan rendah disesuaikan dengan karakter boneka tangan saat bercerita pada anak. Hal ini dapat membantu para ibu bercerita lebih menyenangkan.

\section{Kelas Anak}

1) Gawai untuk Meningkatkan Kreatifitas Anak

Anak usia dini menggunakan gawai sebagai alat bermain yang kurang merangsang otot besar bergerak dan berpikir kreatif. Anak cenderung pasif karena hanya menerima secara satu arah. Oleh karena itu, dilakukan kegiatan pemanfaatan gawai sebagai media inspirasi anak untuk berkreatifitas. Anak diajak membuat kaki dinosaurus dari kardus dan kertas berwarna yang diinspirasi dari video yang ditonton anak. Hal ini untuk menunjukkan pada anak, bahwa gadget dapat dimanfaatkan sebagai inspirasi berkreatifitas.

\section{2) Membuat Perpustakaan Pohon}

Kegiatan membuat perpustakaan ini dilakukan pada pertemuan kedua untuk mendukung keberjalanan One Book One Children (OBOC) yang ingin meningkatkan literasi anak dengan peningkatan sumberdaya buku di sekolah dan rumah (Adams dan Van der Gaag, 20011). Anak diajak mendesain tempat buku yang menarik minat mereka untuk terlibat dalam program OBOC. Kegiatan diawali dengan merangkai tali berwarna-warni dengan penjepit buku yang kemudian dikaitkan pada ranting-ranting pohon di depan sekolah. Selain itu, tali dibuat sebanyak jumlah anak di sekolah, sehingga setiap anak memiliki kesempatan untuk menggantung kembali buku yang telah dibaca dan meminjam buku yang lain dengan mandiri. Guru dapat membantu anak menggantung buku-buku yang dapat anak pinjam atau baca.

Kegiatan ini disambut antusias oleh anak, guru dan orang tua. Orang tua mendapat tugas untuk mendampingi anak membaca dan guru mendapat tugas mengontrol anak menukarkan bukunya dengan buku yang lain, sehingga setiap anak dapat membaca seluruh buku yang disediakan.

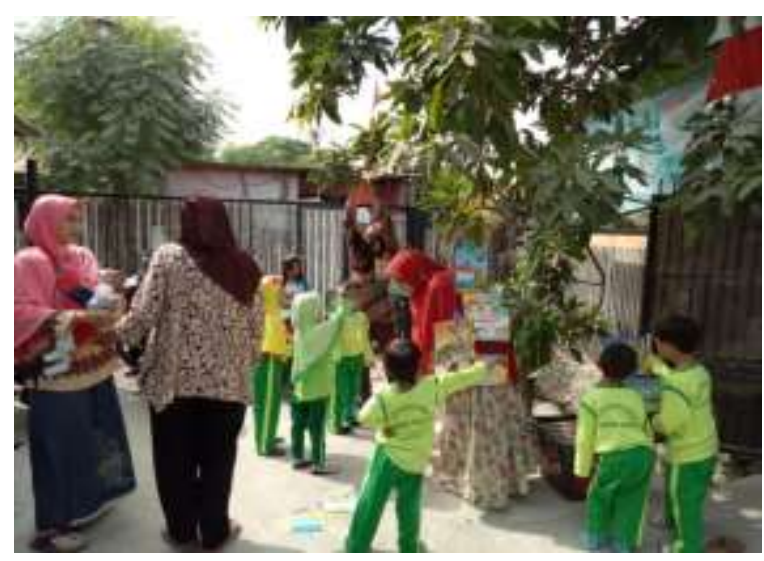

Gambar 3. Anak-anak menggantungkan buku-buku di pohon bersama guru

3) Mewarnai Huruf Bergambar dan Bercerita

Mewarnai adalah aktivitas seni yang biasa dilakukan anak usia dini. Pada pertemuan ketiga ini, kegiatan mewarnai huruf bergambar dilakukan dalam rangkaian kegiatan berbahasa (membaca dan bercerita). Anak diberikan kebebasan memilih huruf bergambar yang disukai, kemudian mewarnainya hingga selesai. Anak yang sudah selesai mewarnai dapat bercerita tentang huruf dan gambar yang dipilihnya.

Sebagian besar anak-anak bercerita dipengaruhi konten cerita dalam buku yang telah dibaca sebelumnya atau pengalaman anak yang berkaitan dengan gambar dan huruf tersebut. Selama kegiatan bercerita, 
anak-anak terlihat memiliki kosa kata yang lebih beragam. Hal ini dimungkinkan berkaitan dengan kegiatan OBOC yang sudah dilakukan selama dua pekan.

\section{4) Membuat Bingkai Foto dari Stik Eskrim}

Anak usia dini memiliki kelekatan yang tinggi pada keluarga. Hal ini dipengaruhi oleh pemenuhan kebutuhan fisik dan psikis yang dominan didapat dari keluarga. Program literasi membaca yang diinisiasi, memanfaatkan kelekatan anak dengan orang tua, khususnya ibu sebagai modal utama. Oleh karena itu, pada program keempat, tim membuat sebuah kegiatan awalan yang menstimulus adanya kegiatan baru atau lanjutan yang dapat dilakukan anak-orang tua bersama-sama melibatkan pengalaman keaksaraan yang didapat selama program OBOC dilaksanakan.

\section{Evaluasi Program}

Secara keseluruhan, kegiatan yang telah dilakukan berjalan dengan baik dan lancar, bahkan di luar ekspektasi program ini diminati oleh para ibu disekitar TK Nurul Fikri. Tim menyadari bahwa peningkatan pemahaman orang tua tentang literasi membaca seharusnya dilakukan dalam kuantitas pertemuan yang lebih banyak, karena mengubah paradigma orang tua terhadap urgensi literasi harus dilakukan secara terus menerus hingga terbentuk perilaku yang menetap. Setelah dievaluasi, tidak semua ibu mendampingi anaknya untuk membaca buku dari program OBOC. Hal ini bisa dipengaruhi ketidakpahaman ibu atau karena kesibukannya. Selain itu, tingginya antusiasme anak-guru dalam program OBOC belum diimbangi dengan jumlah buku yang tersedia di sekolah.

Selain itu, dalam program OBOC, ketersediaan tempat untuk membuat perpustakaan yang menarik belum terpenuhi dengan baik. Pohon yang digunakan sebagai perpustakaan pohon terletak dihalaman sekolah dan tidak terlindungi oleh pagar atau yang sejenisnya. Hal ini mengakibatkan sulitnya pemeliharaan tali-tali yang digunakan untuk menggantung buku. Sebagai saran, guru dapat menyediakan pohon buatan yang dapat diletakkan di dalam ruang sekolah untuk menjaganya dari kerusakan yang berasal dari luar sekolah. Guru juga dapat membuat kontrak kesepakatan dengan anak-anak untuk saling menjaga pohon tersebut dan juga buku-buku yang tergantung. Sehingga anak-anak juga dilatih untuk bertanggung jawab dan menjaga barang milik bersama, selain membiasakan anak untuk membaca buku di pagi hari sebelum kelas dimulai.

Disisi lain, pelatihan mendongeng untuk orang tua juga belum diikuti dengan praktik langsung mendongeng dari orang tua dengan kuantitas yang memadai. Selain karena terbatasnya waktu, banyaknya pertanyaan orang tua terkait permasalahan perkembangan anak pada pemateri membuat pemateri hanya dapat memperagakan contoh mendongeng dalam waktu yang terbatas. Hal ini menjadi caatan perbaikan kedepan, di mana program pelatihan mendongeng harus lebih difokuskan sehingga program ini benarbenar melahirkan para ibu yang memahami urgensi bercerita dan terampil bercerita sebagai sarana edukasi nilai positif pada diri anak, serta sarana untuk meningkatkan budaya literasi dirumah.

\section{PENUTUP}

\section{Simpulan}

Peran orang tua memberikan teladan sangat penting dalam meningkatkan literasi anak dirumah. Disisi lain, guru disekolah harus memiliki sense of literacy culture yang dapat mendorong kreatifitas dalam proses belajar mengajar. Pemahaman yang baik dari 
orang tua dan guru kemudian mendekatkan buku-buku pada anak disertai penyediaan berbagai media bercerita yang dibuat langsung oleh orang tua dapat membangun budaya literasi sesuai kemampuan yang ada.

Kelas parenting dapat membuka wawasan orang tua dan guru untuk menguatkan perannya dalam membentengi anak dari pengaruh buruk gawai, memaksimalkan fungsi positif gawai, serta melatih mengembangkan media dan bahan cerita yang sesuai untuk anak-anaknya dalam rangka mendukung peningkatan literasi.

Adapun terbatasnya jumlah dan durasi waktu pertemuan, tidak adanya kontrol peneliti terhadap orang tua ketika dirumah, serta lemahnya komitmen orang tua ketika menghadapi kesibukan sehari-hari membuat aktivitas peningkatan literasi di rumah belum optimal. Selain itu, terbatasnya sumber dukungan sekolah juga menjadi faktor kurang maksimalnya kegiatan kelas parenting dan kelas anak yang dilakukan.

\section{Saran}

Program pemberdayaan yang telah dilakukan ini dapat dilakukan di tempat lain dengan menganalisis kebutuhan dan keadaan sasaran terlebih dahulu. Adapun yang harus diperhatikan bahwa kelas-kelas parenting untuk menguatkan kesadaran dan pengetahuan mengenai budaya literasi hendaknya dilakukan secara berkala dan diikuti dengan pendampingan dan kontrol yang memadai sehingga perubahan perilaku sebagai hasi belajar dari program pemberdayaan dapat bertahan dan mengkristal pada diri orang tua. Selain itu muatan kelas parenting harus seimbang antara materi konseptual dan praktik, sehingga orang tua tidak hanya mengetahui hal-hal yang penting dalam perkembangan anaknya, namun juga menguasai keterampilan yang berkaitan dengan hal-hal teknis di lapangan.

\section{E. DAFTAR PUSTAKA}

Adams, A. and Van der Gaag, J. 2011. First Step to Literacy: Getting Books in the Hands of Children. [serial online] 2011 [cited 2018 April 10]. Available from URL: https://www.brookings.edu/research/ first-step-to-literacy-getting-booksin-the-hands-of-children/

BPS. 2015. Indikator Sosial Budaya 2003, 2006, 2009, 2012, dan 2015. [serial online] 2015 [disitasi pada 7 April 2018. Tersedia melalui URL: https://www.bps.go.id/linkTableDina mis/view/id/1234.

CCSU. 2016. World's Most Literate Nations Ranked. [cited 2018 April 7]. Available from URL: https://webcapp.ccsu.edu/?news $=176$ $7 \&$ data.

Freire, P. et al. 2005. Literacy: Reading the Word and the World. United Kingdom: Taylor \& Francis eLibrary.

Kemendikbud. 2016. Rangkuman Statistik Pendidikan Dasar dan Menengah 2016/2017. Jakarta: Kementrian Pendidikan dan Kebudayaan Republik Indonesia.

Miller, S. and Pennycuff, L. 2008. The Power of Story: Using Storytelling to Improve Literacy Learning. Journal of Cross-Disciplinary Perspectives in Education. 1: 36-43.

Social, W. A. and Hootsuite. 2017. Digital in 2017: Southeast Asia. A study of internet, social media, and mobile use throughout the region. [serial online] 2017 [cited 2018 Nov 2]. Available 
from

URL:

https://wearesocial.com/special-

reports/digital-southeast-asia-2017

Suryanto, B. 2005. Pemberdayaan Komunitas Marginal di Perkotaan, dalam Dakwah Pemberdayaan Masyarakat, Paradigma Aksi Metodologi. Yogyakarta: Pustaka Pesantren. 